\title{
A külkereskedelem akadályainak számszerúsítése egy magyarországi élelmiszer-gazdasági külkereskedelmet vizsgáló gravitációs modellben SZÉKELYHIDI KATALIN
}

Az utóbbi évtizedekben a nemzetközi kereskedelmi kapcsolatok elmélyitése és az egymás közötti korlátok csökkentése egyre hangsúlyosabbak. Egyre több kereskedelmi megállapodás, egyezmény születik országok között, a meglévő integrációk pedig egyre csak bövülnek. Ez a folyamat napjainkban sem áll meg, hiszen világszerte folynak a tárgyalások lehetséges kereskedelmi egyezmények megkötéséröl. Éppen ezért érdekes kérdés annak vizsgálata, hogy milyen tényezök játszanak szerepet egyegy ország külkereskedelmi tevékenységében, illetve hogy a létrejövö integrációk és az ennek során leépítésre kerülö vámok és nem vámjellegü akadályok mekkora hatással vannak az országok külkereskedelmére. A tanulmányban Magyarország élelmiszer-gazdaságának külkereskedelmét modellezem gravitációs modell segitségével, amelynek legjelentösebb újítása, hogy egy olyan változót is alkalmazok benne, amelyet az eddigi kutatások során még nem alkalmaztak. A mutató a nemzetközi kereskedelem legfóbb korlátait, a vámokat és nem vámjellegü akadályokat számszerüsíti egyetlen indexben. A modell eredményei alapján a mutató a jövöben hosszú idősoron használható lehet a külkereskedelmi termékforgalom magyarázatában. Journal of Economic Literature (JEL) kód: C51, F15.

Napjainkban már alig akad olyan ország, amely nem vesz részt a globális gazdaság folyamataiban, hiszen az elmúlt évtizedek tapasztalatai azt mutatták, hogy a világ gazdaságai egyre inkább felismerik a külkereskedelemből származó előnyöket, így egyre több kereskedelmi megállapodás, egyezmény, regionális integráció szüle-

https://doi.org/10.47630/KULG.2017.61.5-6.46

Székelyhidi Katalin, PhD-hallgató, Szegedi Tudományegyetem. E-mail: kata.szekelyhidi@gmail.com 
tik. A WTO-tárgyalások a 2000-es évek óta húzódnak, de átütő eredmények eddig nem születtek. Emiatt az egyes országok, országcsoportok érdeklődése a kétoldalú kereskedelmi megállapodások felé fordult. A kétoldalú szabadkereskedelmi kapcsolatok terjedését az is elősegítette, hogy rugalmasabban alakíthatók a feltételek, egyszerübb kezelni az érzékeny területeket. Éppen ezért egyre hangsúlyosabbá vált a külkereskedelmet befolyásoló tényezők meghatározása és azok hatásainak számszerüsítése. Az ilyen típusú elemzések általánosan használt eszköze a gravitációs modell. A gravitációs modell alkalmas egyrészt annak a feltérképezésére, hogy milyen tényezők befolyásolják a külkereskedelmi forgalmat (legyen az import vagy export), másrészt arra, hogy a már életbe lépett integrációk, egyezmények hatásait vizsgáljuk. A gravitációs modellt Newton gravitációs törvényéből vezették le, használata mára már hosszú múltra tekint vissza a társadalomtudományokban, és az utóbbi évtizedekben elméleti alapozása is megszületett. Ugyanakkor nincs egy általánosan elfogadott modellezési keret, amely minden kereskedelmi kapcsolat vizsgálatára alkalmas lehet.

A tanulmányban Magyarország élelmiszer-gazdaságának külkereskedelmét befolyásoló tényezőket modellezem 2015-re vonatkozóan a gravitációs modell segítségével, amely során új elemként egy olyan magyarázóváltozót is szerepeltetek, amelyre az eddig lefolytatott kutatásokban nem volt példa. Ez a mutató a külkereskedelmi lehetőségek foka, amely a vámok és nem vámjellegű akadályok hatásait számszerüsíti. Ez utóbbiak közgazdaságtani hátterét az integrációelméletek magyarázzák, így a tanulmányban elsőként ezeket mutatom be, kitérve a regionalizmus korai gondolataira a vámok leépítésével kapcsolatban, majd a mai, sokkal összetettebb és a vámok leépítésén messze túlmenő integrációk speciális jellegzetességeit vizsgáló újregionalizmust, amely szorosan kapcsolódik a nem vámjellegủ akadályokhoz is. A tanulmány következő részében bemutatom általánosan a gravitációs modellt és annak statisztikai hátterét. Ezután sorra veszem a modell gyakorlati alkalmazását az élelmiszer-gazdaság külkereskedelmének modellezésére vonatkozóan, hogy képet kapjak arról, milyen modellek és milyen magyarázóváltozók bizonyultak sikeresnek a termékforgalom magyarázatában. A tanulmány utolsó részében ismertetem a magyarországi élelmiszer-gazdaság külkereskedelmének gravitációs modelljét és a kapott eredményeket. 


\section{Integrációelméletek}

A világ országai az utóbbi évtizedekben egyre inkább felismerték, hogy a külkereskedelemből származó előnyök fokozhatók, ha továbblépnek az egyszerü termékforgalom szintjéről és lépéseket is tesznek megkönnyítése érdekében. Ennek okán az országok egymással szabadkereskedelmi egyezményeket, megállapodásokat kötnek a vámok csökkentésére és eltörlésére, sőt országok, régiók egymással még szorosabb kapcsolatot is létesítenek integrációk keretében. Az integrációt gyakran regionalizmusként is emlegetik, amely gyakorlatilag a regionális egyezmények bármilyen formáját magában foglalja, a különálló nemzetgazdaságok nagyobb gazdasági blokkokká vagy közösségekké történő intézményi összekapcsolódásaként definiálható (Robson, 2002). Az integrációnak különböző fokozatai vannak, amelyek egyre szorosabb kapcsolatot hoznak létre országok között, minél jobban elmélyítve ezzel a külkereskedelmet is. Az integráció olyan esetben is fokozza a külkereskedelmet, ha az integráció előtt már létezett szabadkereskedelmi egyezmény, tehát nem pusztán a vámok leépítése növeli a termékforgalmat. Ezt kutatási eredmények is alátámasztják. Magyarország az EU-csatlakozás előtt már érvényben lévő szabadkereskedelmi megállapodást kötött az EU-val, így jó néhány termékkategória esetén elenyésző nagyságú vagy nulla volt a vámtétel. Azonban a csatlakozás után az adminisztratív terhek csökkenése még tovább mélyítette a külkereskedelmi kapcsolatokat olyan termékek esetében is, ahol már korábban eltörölték a tarifákat (Kürti et al., 2007). Az integrációk történelmét jellemzően két nagy részre szokták tagolni. Az 1950-es és 1960-as évek voltak az integrációs törekvések első jelentősebb időszakai, amelyek jellemzően az európai integráció köré fonódtak. Ez az időszak a regionalizmus, a regionális integráció első hulláma, amely jellemzően a vámok leépítésének hatásaival foglalkozik. A második időszak az új regionalizmus időszaka, amelyet az 1980-as évek közepétől számítunk, és amely a regionalizmust világméretủ jelenségnek tekinti. Az újregionalizmus a vámleépítésnél sokkal tágabban értelmezi, figyelembe véve az integrációk létrejöttének tágabb gazdasági hatásait is.

Vámunió-elmélet

A korai integrációelméletek központi eleme tehát a vámok egymás közötti leépítése hatásainak vizsgálata. Jacob Viner 1950-ben jelentette meg gondolatait a vámok hatásairól és változtatta meg ezzel a korábbi vámokkal kapcsolatos elméleteket. Gondolatai a regionális integrációk vizsgálatának központi elemei voltak egészen 
az újregionalizmus felvirágzásáig. Viner a vámuniónak két hatást tulajdonított: az egyik a kereskedelemteremtés, a másik pedig a kereskedelemeltérítés. Előbbi akkor jelenik meg, amikor a vámok leépítése következtében az országok azért importálnak, hogy a hazai magas költségü elöállítást helyettesítsék a külföldi olcsóbb gyártással. A vámunió másik következménye lehet a kereskedelemeltérítés, amely esetén a vámunió hatására az új partnerország számára adódik lehetőség beszállítói pozícióra, holott lehet, hogy a korábbi partnerország alacsonyabb költségekkel állította elő ugyanazt a terméket. Az elmélet szerint előbbi tekinthető pozitív folyamatnak, míg utóbbi negatív hatása a vámuniónak (Lipsey, 1957).

A kereskedelemteremtés során az olcsóbb külföldi partnerek kerülnek jobb helyzetbe költségelőnyük miatt, és így új kereskedelmi kapcsolat jön létre. Az exportáló ország számára tehát egyértelmüen előnyös, hogy termékével bejut egy új piacra. Ugyanakkor közelebbről megvizsgálva, az importáló ország számára előnyös és hátrányos is lehet. Kedvező lehet a fogyasztók szemszögéből, hiszen a korábbi drágább terméket felváltja az olcsóbb termék a piacon, viszont az olcsóbb külföldi termékek hazai cégeket szoríthatnak ki a piacról. Kereskedelemeltérítés esetén a harmadik ország nem tagja az integrációnak, ezért a vámokat ugyanúgy meg kell fizetnie, így magasabb áron adja a terméket, mint az integrációs partnerország, ezért elesik az üzlettől. Ez előnyös az új partnerországnak és részben az importáló országnak, hiszen előbbi piacot szerez, utóbbi olcsóbb termékhez jut. Ugyanakkor tény, hogy az importáló ország ezentúl a kevésbé hatékony országtól szerzi be a terméket és elveszít egy bejáratott kereskedelmi kapcsolatot, illetve a harmadik országgal való kereskedelemből származó vámbevételt. Viner elméletében éppen ezért a kereskedelemteremtés és a kereskedelemeltérítés egymáshoz viszonyított aránya mutatja meg az integráció jólétet növelö hatását (Clasuing, 2001).

A vámok eltörlésének előnyei végső soron a kereskedelemteremtés és kereskedelemeltérítés egyenlegéből adódnak. Ez az egyenleg számos tényezőtől függ, amelyek közül a legjelentősebbek Palánkai [2004] alapján:

- Az eltörölt vámok mértéke: Annál nagyobb lesz a kereskedelemteremtés mértéke, minél magasabb szintű vámokat töröltek el az integráció keretein belül, hiszen korábban a magas vámokkal védték a kevésbé hatékony iparágat.

- Az integráció gazdasági mérete és területe: A vámunió hasznai annál jobban érvényesülnek, minél nagyobb az unió gazdasági mérete, ezzel szemben a kereskedelemeltérítés annál jobban jellemző, minél kisebb az unió gazdasági mérete. 
- A szállítási költségek fontossága: A szállítási költségek nagymértékben befolyásolják a két ország közötti kereskedelem mértékét és ennek szoros kapcsolata van az unió méretével is. Kifejezetten igaz ez nagy méretủ integráció esetében. Ennek oka az, hogy amennyiben egy tekintélyes földrajzi kiterjedésủ unióról beszélünk, úgy a szállítási költségek igen magasak lehetnek, ezért a közelebbi partnerek előnyben részesülhetnek a távolabbiakkal szemben. Több tanulmány szerzője felhívja rá a figyelmet, hogy a szállítási költségek sok esetben nagyobb gátat jelentenek a kereskedelem elött, mint maguk a vámok (Limao-Venables, 2001; Clark et al., 2004; Hummels, 2007). A szállítási költségek egyik részét, azaz a távolság hatását általában gravitációs modellel számszerüsítik, és gyakran a távolságot használják proxyként a szállítási költségek meghatározására. A témában született tanulmányok egyértelmüen kimutatják, hogy negatív kapcsolat áll fenn a két ország közötti távolság és a termékforgalom nagysága között. Az értékbeli világkereskedelmi forgalom 23 százaléka olyan országok között zajlik, amelyek közös határral rendelkeznek (Hummels, 2007).

- Az országok gazdasági szerkezete: Minél hasonlóbb a termékstruktúrája két országnak és ezeket a termékeket nagy költségkülönbséggel állították elö, annál jövedelmezőbb lesz a felek számára a vámunió (Palánkai, 2004).

A fentiekben említett vámuniós hatások a statikus hatásokat összesítő vámunióelméletek közé tartoznak. Emellett megkülönböztetünk dinamikus hatásokat is. A dinamikus hatásokat sokan nagyobb mértékünek becsülik, mint a statikus hatásokat. Ezek közé tartoznak a méretgazdaságosságból származó előnyök, a megnövekedett verseny, amelynek hatására a hazai cégek felzárkózhatnak, a beruházások ösztönzése és a termelési tényezők hatékonyabb kihasználása (Scitovsky, 1958; Michalopoulos és Tarr, 2004; Salvatore, 2004).

\section{Újregionalizmus}

A Viner által létrehozott vámelméleteket sokáig használták elméleti keretként a kereskedelem magyarázatára, ugyanakkor az elmúlt évtizedekben elmélyülő kereskedelmet és összetettebb integrációkat pusztán a vámok kereskedelemteremtő és -eltérítő elméletei már nem magyarázzák teljeskörüen. A korábbi elméletek lényegében az Európai Unió létrejöttével egy időben és annak magyarázatára jöttek létre, azonban az 1980-as évektől kezdődő új típusú integrációk és nemzetközi környezet vizsgálatára már kevésbé alkalmasak. Egyrészt mára már sokkal mélyebbé vált az iparosodott országok között a feldolgozott termékek kereskedelmének liberalizáltsá- 
ga. Továbbá a regionalizmus klasszikus időszaka alatt, a még gazdaságilag kevésbé fejlett, a kereskedelemtől és a tőke áramlásától elzárkózó országok napjainkban egyre inkább arra törekednek, hogy becsatlakozzanak a globális multilaterális kereskedelmi rendszerbe. Az új nemzetközi gazdasági környezet harmadik jellemzője a külföldi müködő tőke intenzív áramlása a fejlett és fejlődő országok között. Az új regionalizmus korszakának egyik legfontosabb jellemzője, hogy a regionalizmus világméretűvé vált, a világ különböző pontjain más jellegzetességekkel rendelkezik, különböző típusú integrációk jönnek létre (Söderbaum, 2003; Hettne, 2005).

Az ilyen integrációk az újregionalizmus keretében az alábbi közös jellemvonásokkal rendelkeznek (Ethier, 1998; Burfisher et al., 2004):

- Jellemzően egy vagy több kis ország egy nagy országgal kerül valamilyen mélységủ integrációba vagy regionális egyezménybe. A NAFTA esetében Mexikó és Kanada az USA-hoz képest viszonylagosan kis országnak minősül gazdasági szempontból, de ugyanez elmondható az EU esetében például a 2004-es keleti bővítés kapcsán. A MERCOSUR-ban Brazília is egyértelmủen meghatározó ország a többi taggal szemben;

- A kis országok jellemzően több területet is érintő reformokat vezetnek be, ide sorolható például a kelet-közép-európai országok rendszerváltása és az EU-csatlakozás óta véghez vitt harmonizációs törekvések;

- Nem jellemzőek a drasztikus lépések a szabadkereskedelem elérése érdekében, általában kisebb lépésekben liberalizálják a kereskedelmet. Például sok esetben mezőgazdasági termékekre vonatkozóan szerényebb mértékủ vámcsökkentést hajtanak végre, esetleg több lépcsőben, évek alatt valósítják meg a vámtételek eltörlését vagy érzékeny termékek esetében fenntartják a védelmet. Mindez mutatja a Viner-elmélet hibáját is, hiszen a vámtételeket nem egységesen és nem azonnal, nem feltétlenül teljes mértékben törlik el;

- Sok esetben a liberalizációt a kis ország valósítja meg azáltal, hogy a kis ország tesz engedményeket, tehát az egyezmények egyoldalúak, nem kizárólag a vámok leépítését tekintve, hanem az intézményi rendszer átvételét tekintve is, például az EU esetében is, ahol a csatlakozó országnak kell alkalmazkodnia a rendszerhez. De példaként említi a szerző a NAFTA-t is, ahol Mexikó és Kanada több kedvezményt tett, mint az Egyesült Államok. Ennek oka abban is kereshetö, hogy a nagy ország sok esetben eleve alacsonyabb vámszintekről indul, mint a csatlakozó kis ország; 
- Az újregionalizmusban kialakulnak mélyebb integrációk is, amelyekben nem pusztán a kereskedelem korlátjainak leépítéséről van szó, hanem a gazdasági politikák összehangolásáról is;

- A regionális egyezmények, integrációk földrajzi értelemben is regionálisak, azaz a résztvevők szomszédos országok.

\section{A gravitációs modell bemutatása}

A külkereskedelmi termékforgalom modellezésére két fő módszer különböztethető meg, az egyik a parciális és általános egyensúlyi modellek, a másik pedig a gravitációs modell. Előbbi jellemzően ex ante elemzésekre alkalmas, azaz integrációk, egyezmények lehetséges következményei modellezhetők segítségével. Utóbbi, a gravitációs modell a legszélesebb körben alkalmazott eszköz a külkereskedelmi termékforgalom modellezésére. Jellemzően ex post elemzésekre alkalmas, azaz életbe lépett egyezmények, integrációk bekövetkezett hatásai figyelhetők meg segítségével. Tinbergen és Pöyhönen egymástól függetlenül, szinte egy időben, 1962-ben és 1963-ban hozták létre a gravitációs modellt, azóta rendkívül népszerủ lett számos jelenség vizsgálatára. Jellemzően különböző típusú áramlások modellezésére szolgál, úgymint migráció, külföldi befektetések, de leginkább a külkereskedelmi forgalom leképezésére használatos. A modell lényegében egy regressziós modell, amely egyrészt alkalmas arra, hogy feltérképezzük, hogy területi egységek közötti termékforgalom hogyan magyarázható, milyen tényezők játszanak szerepet az áramlások alakulásában. Segítségével feltárható a különböző befolyásoló tényezők és a termékforgalom közötti ok-okozati kapcsolat. Másrészt a modell már továbbfejlesztett változatai alkalmasak időbeli vizsgálatokra, azaz becsülhető, hogy egyezményeknek, megállapodásoknak, integrációhoz történő csatlakozásnak milyen hatása volt a külkereskedelemre (Garcia et al., 2013).

A Tinbergen és Pöyhönen által az 1960-as években lefektetett alapmodell két ország közötti termékforgalom nagyságát az országok méretével és a szállítási költséggel magyarázta. Előbbit a nemzeti jövedelemmel, utóbbit a két ország központja közötti távolsággal ragadta meg. A következtetések alapján minél nagyobb az országok jövedelme és minél kisebb két ország között a szállítási költség, annál nagyobb lesz közöttük a termékforgalom. Linnemann [1966] a népességgel bővítette a magyarázóváltozók körét (Cheng-Wall, 2005). A modell illeszkedése jónak bizonyult és széles körben használták is az elkövetkező évtizedekben, azonban elméleti magya- 
rázata sokáig hiányzott, de az 1960-as évektől ennek kidolgozása is megkezdődött és napjainkban már közgazdaságtani háttere is alátámasztott.

A kereskedelem gravitációs modellje az országpárok közötti export nagyságát az országok jövedelme, népessége, a közöttük lévő távolság és egyéb dummy változók függvényében határozza meg.

A szakirodalmak alapján a gravitációs modell alapegyenlete egy időszakra vonatkozóan

$$
X_{i j}=\beta_{0} Y_{i}^{\beta_{1}} Y_{j}^{\beta_{2}} P_{i}^{\beta_{3}} P_{j}^{\beta_{4}} D_{i j}^{\beta_{5}} A_{i} A_{j} A_{i j} \varepsilon_{i j},
$$

ahol: $X_{i j}$ az $i$ országból a $j$ országba irányuló export nagysága, $Y_{i}\left(Y_{j}\right)$ az országok jövedelme, amely a GDP-vel ragadható meg, $P_{i}\left(P_{j}\right)$ az országok népessége, $D_{i j}$ a két ország közötti távolság, $\beta$ a magyarázóváltozók együtthatói. Továbbá $A_{i}, A_{j} A_{i j}$ az $i$ országra, $j$ országra és kettejük kapcsolatára jellemző dummy változók, amelyek minőségi, specifikus jellemzői az országoknak vagy országpároknak, és amelyek meghatározzák a két partner közötti kapcsolatot. A dummy változó segítségével vizsgálható, hogy például a közös nyelv, a közös határ, a tengerparttal való rendelkezés, gyarmati múlt vagy egy integrációban, szervezetben, egyezményben való részvétel hogyan befolyásolja a két fél közötti kereskedelmet. A dummy változó 1-es értéket vesz fel, ha az ország vagy országpár felveszi az adott tulajdonságot, például közös nyelvet beszélnek, és 0 érték jelenik meg, ha nem rendelkezik az említett jellemzővel.

A fenti gravitációs alapegyenlet multiplikatív formában írja fel a kereskedelem modelljét, amelynek logaritmusát véve az egyenlet lineáris formára hozható, így egy egyszerü loglineáris regressziós egyenletet kapunk, amely a regresszió elemzés eszköztárával vizsgálható.

A gravitációs modell alapvető loglineáris egyenlete a következő:

$\ln x_{i j}=\ln \beta_{0}+\beta_{1} \ln Y_{i}+\beta_{2} \ln Y_{j}+\beta_{3} \ln P_{i}+\beta_{4} \ln P_{j}+\beta_{5} \ln D_{i j}+A_{i}+A_{j}+A_{i j}+\mu_{i j}$

A modell logikája szerint minél nagyobb az exportáló ország jövedelme, annál nagyobb szintű lesz a termelése, ezáltal annál nagyobb lesz az export alapja. Éppen ezért $\beta_{1}$ együttható értéke várhatóan pozitív. Ugyanezen logika mentén $\beta_{2}$ is pozitív, hiszen minél nagyobb az importáló ország jövedelme, annál több terméket tud külföldről vásárolni. Ezzel szemben a népességgel kapcsolatban már nem ilyen egyértelmü a koefficiensek előjele, $\beta_{3}$ és $\beta_{4}$ lehet pozitív és negatív is, attól függően, hogy az abszorpciós vagy a méretgazdaságossági hatás érvényesül. Az előbbi következtében egy ország nagy méretéhez képest keveset exportál és ezért negatív lesz 
az együttható előjele; az utóbbi szerint pedig ha nagyobb egy ország, akkor többet exportál, és ezért pozitív lesz az együttható elöjele (Martinez-Zarzoso, 2003).

A gravitációs modellt sokáig csak keresztmetszeti adatokra használták, azaz egy időpontra vetített adatokat elemeztek segítségével. A panel adatok alkalmazásának lehetőségével az ezredforduló előtti néhány évben kezdtek el foglalkozni, egyre többen jutottak arra a következtetésre, hogy idősoros adatokkal pontosabb becslés kapható.

\section{A gravitációs modell alkalmazása az agrár-külkereskedelemben}

A gravitációs modellek használata az elmúlt évtizedekben általánossá vált a külkereskedelmi termékforgalom alakulásának magyarázatában, illetve egyezmények, integrációk hatásainak vizsgálatában. A modellt széles körben használják a mezőgazdaságban és az élelmiszeriparban is a 2000-es évek eleje óta, amelynek oka lehet, hogy az ezredfordulót megelőző 20 évben születtek olyan egyezmények, melyek hatásai hosszabb idősoron vizsgálhatóvá váltak 2000-től.

Az amerikai földrészen végbement kereskedelmi egyezmények (NAFTA és MERCOSUR) hatásait széles körben tanulmányozták többek között az élelmiszergazdaság termékeire vonatkozóan is (1. táblázat). A kutatások eredményei rávilágítottak, hogy Mexikó 1980-as években történő piacnyitása sokkal nagyobb mértékben növelte az USA exportját az országba, mint más piacokra. Ugyanakkor a NAFTA hatásai ehhez képest alacsonyabbnak tủntek, inkább néhány termékcsoport esetében volt meghatározó. Továbbá a MERCOSUR megalakulásával az USA kereskedelmi kapcsolatai megcsappantak Brazíliával, föként a tej, tejföl, hüvelyesek és a búza esetében (Zahniser et al., 2002).

Egy másik kutatás szintén a NAFTA kereskedelemteremtő és kereskedelemeltérítő hatásaival foglalkozott hat mezőgazdasági termékkategória esetében (vörös húsok, gabonák, zöldségek, gyümölcsök, cukor és olajos magvak). Az eredmények azt mutatták, hogy a 6 termékből 5 esetében a NAFTA csökkentette az országok nyitottságát és az egyezményben részt vevő országok között a NAFTA életbe lépése után növekedett a kereskedelem (Jayasinghe-Sarker, 2007).

A mezőgazdaság kereskedelmével általánosságban is foglalkoztak kutatások, amelyek próbálták magyarázni tendenciáinak alakulását. Az egyik ilyen 2008-ban lefolytatott kutatás megállapította, hogy 1990 és 2002 között a mezőgazdasági kereskedelem általánosan növekedett, de a kevésbé fejlett országokban sokkal kisebb mértékben valósult meg, mint az OECD és az EU esetében. Sőt, a fejlett és a fejlödő országok egymással szemben meglehetősen zártabbá váltak. Kibontva a fentie- 
ket, ha a gazdag ország a NAFTA vagy az EU tagja, akkor sokkal többet exportált, mint más országok, amely a termelőknek fizetett jelentős mértékü támogatás következménye lehet. Továbbá Latin-Amerika és Afrika országai, akiket általában nagyobb mértékben sújt a gazdag országok protekcionista magatartása, maguk is relatíve zártnak bizonyultak és kevesebb terméket importáltak, mint amenynyit gazdasági méretük és más magyarázó tényezők indukálnának (Paiva, 2008).

Egy másik kutatás alapján a 20. század második felében a feldolgozott termékek (nehézipar, könnyüipar és élelmiszeripar együtt) külkereskedelmi forgalma növekedett, nem úgy, mint az élelmiszer-gazdaság termékei, melyek csökkenő részarányt tudhattak magukénak. Ezt mutatja, hogy míg 1951-ben még 43 százalék volt arányuk a világkereskedelmen belül, addig 2000-ben már csak 6,7 százalék, továbbá mennyiségben is számottevő, 20 százalékpontos visszaesés volt tapasztalható. Az eredmények alapján a jövedelmek alakulása meghatározó volt a kereskedelem alakulásában, de amíg a feldolgozóipari termékek esetében a jövedelem pozitív kapcsolatban állt a kereskedelem alakulásával, addig a mezőgazdasági és élelmiszeripari termékek esetében negatív volt a vizsgált közel 40 év alatt. Ez azt jelenti, hogy ezek a termékek inferior termékekként viselkedtek, a jövedelem növekedésével csökkent a fogyasztásuk. További eredménye volt a modellnek, hogy az élelmiszer-gazdaság termékei esetében sokkal fontosabbnak bizonyultak az egyezmények, különösen igaz ez az EU esetében (Serrano-Pinilla, 2012).

Magyarországon is készült néhány gravitációs modell, de nem kifejezetten Magyarország külkereskedelmének vizsgálatára. Egy 2014-es kutatás az ágazaton belüli agrárkereskedelmet vizsgálta a tényezőellátottság függvényében az EU új tagországaiban, többek között a gravitációs modell segítségével. Az eredmények alapján a tényezőellátottság különbségeinek növekedése és a távolság negatívan, ezzel szemben a GDP és az EU-tagság pozitívan befolyásolják a horizontális kereskedelmet. Ez azt jelenti, hogy hasonló tényezőellátottság esetében az országok hasonló termékekkel kereskednek. A modell azt is bizonyította, hogy az új tagországok között jellemzően vertikális kereskedelem érvényesül, azaz különböző minőségü termékeket cserélnek az országok. A tényezőellátottság pozitív irányú kapcsolatban áll a vertikális kereskedelemmel, ami azt jelenti, hogy az eltérő tényezőellátottsággal rendelkező országok egymás között eltérő minőségű termékeket cserélnek (Jámbor, 2014).

Egy következő kutatás az intézmények hatását vizsgálta 1995 és 2003 között az OECD országainak mezőgazdasági és élelmiszertermékekre vonatkozó kereskedelmében. A modellben használt indexek több változót ragadnak meg, amivel a szerzők 
0
0
-0
-0
-0
-1

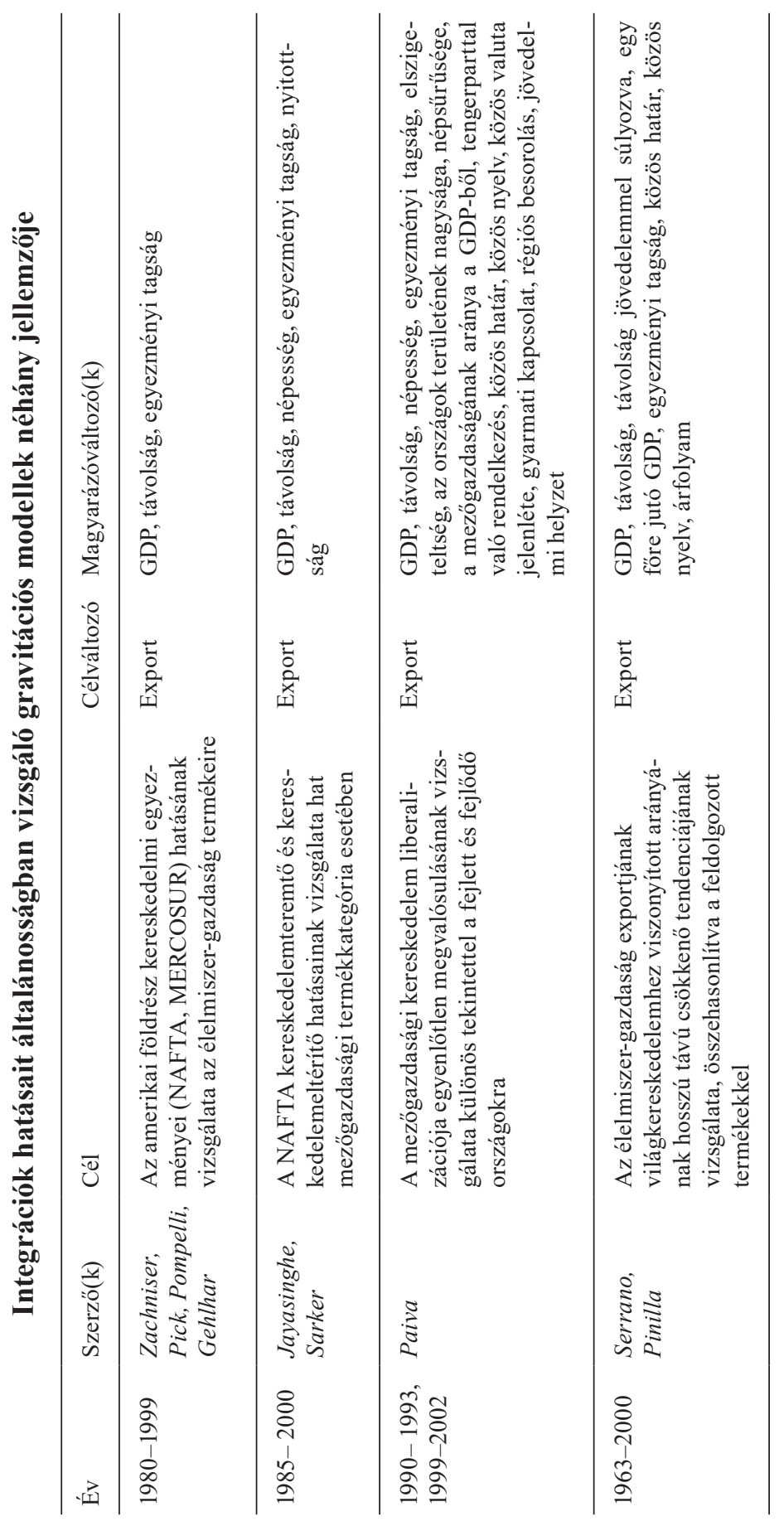




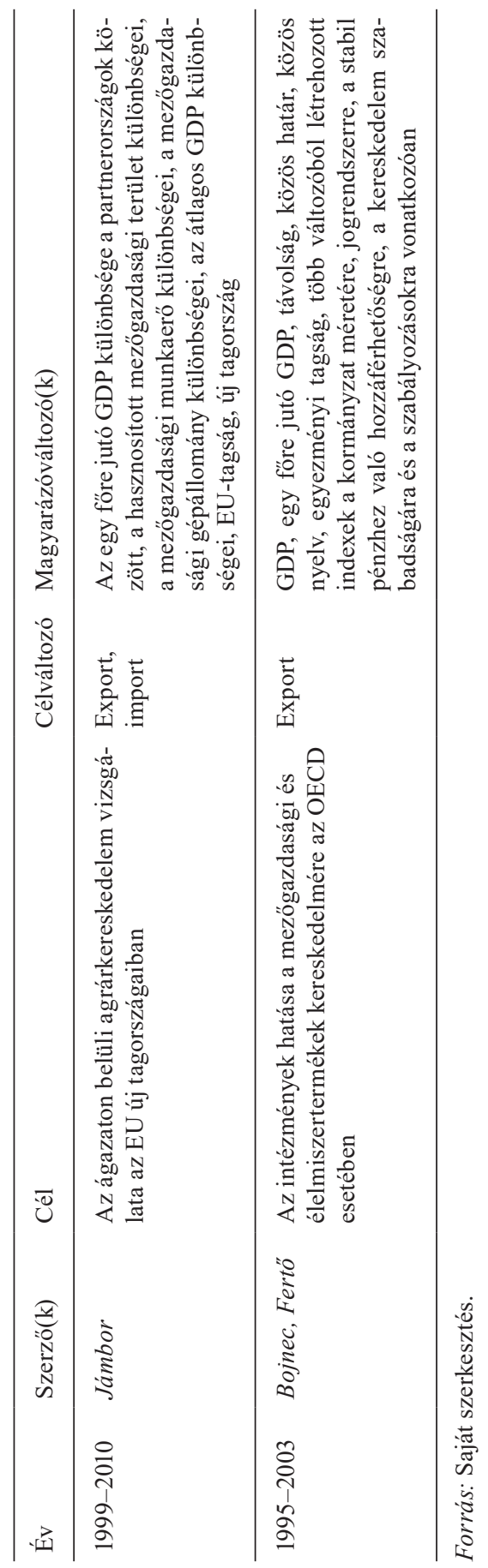


célja az OECD-országok közötti kereskedelem és az intézményi rendszer hasonlósága, illetve az intézmények minőségének szintje közötti összefüggés vizsgálata volt. A modellben elkülönítették a mezőgazdasági termékeket a feldolgozott élelmiszeripari termékektől. Eredményeik alapján a hasonlóság és a minőség is szignifikánsan befolyásolják a kereskedelmet. A hasonlóság mind a mezőgazdasági, mint az élelmiszeripari termékek exportját pozitívan befolyásolja, de a feldolgozott termékek esetében az intézmények hasonlósága jobban növeli a termékek exportját. A magasabb minőségü intézmények szintén pozitívan hatnak a külkereskedelemre mindkét termékkategória esetében. Továbbá az intézmények minőségének javulása csökkenti a távolság negatív befolyásoló hatását (lásd az 1. táblázatot) (Bojnec és Fertö, 2015).

Számos esetben alkalmazták a gravitációs modellt egy-egy ország élelmiszergazdaságának modellezésére (lásd a 2. táblázatot). Ezek között az EU-országok mediterrán országokkal való kereskedelmi kapcsolata is jó néhány kutatás tárgyát képezi. Ennek oka lehet, hogy az EU külpolitikájában különösen fontos szerepet szán ezeknek az országoknak nemcsak a közelség miatt, hanem amiatt is, hogy néhány EU-tagországgal való gyarmati kapcsolat továbbra is érezhetően szerepet játszik a kereskedelemben (Crescimanno et al., 2013). Ezt alátámasztotta egy 2008-ban végzett kutatás, amely a németországi olívaolaj importját vizsgálta és a gravitációs modell alapján azt a következtetést vonták le, hogy a Németországba irányuló exportot jelentősen befolyásolta az, ha egy ország az EU társulási partnerországa (Kavallari és szerzötársai, 2008).

Egy másik, 2013-ban végzett kutatás Olaszország mediterrán országokba irányuló exportját vizsgálta. E kutatás szerint az olasz export növekedett, ahogy a délmediterrán országoktól a balkáni országok felé haladunk. A mediterrán országokkal aláírt egyezmények kismértékủ hatást gyakoroltak a kereskedelemre, ezzel szemben a potenciális tagjelöltekkel kötött egyezmények hatékonyabbak voltak a kereskedelem ösztönzésében, hiszen a kereskedelemkorlátozások sokkal enyhébbek a tagjelölt országok esetében (Crescimanno et al., 2013).

Angulo és szerzőtársai [2011] Tunézia olívaolaj-exportját modellezték, különös tekintettel a legfontosabb felvevő országokra, úgymint: Olaszország, USA, Spanyolország, Marokkó, Franciaország és Svájc. Az elemzésüket a térökonometria eszköztárával is kibővítették, ami a szerzők szerint a térbeli dinamika megragadása miatt szükséges, ugyanis az egymáshoz közel elhelyezkedő területi egységek hasonló tulajdonságokat vesznek fel és befolyásolják egymást. A modell eredményei alapján a gravitációs modelltől megszokott kapcsolatok tapasztalhatók, továbbá a térökonometriai 
elemzés alapján az egymással szomszédos importáló országok (Spanyolország, Franciaország és Olaszország) hasonlóságot mutatnak importjaik nagyságát illetően.

Gravitációs modelleket széles körben használtak a Közel-Kelet mezőgazdasági külkereskedelmének vizsgálatára is, amelyek föként Egyiptom csökkenő szerepével foglalkoztak a mezőgazdasági termékek exportját tekintve. Hatab és társai [2010] eredményei alapján az ország exportja magasabb azokban az országokban, ahol arabul beszélnek, illetve az egyezményben való részvétel nem járul hozzá a kivitel növekedéséhez. Ez utóbbi okát abban látták, hogy hasonlóak a komparatív előnyök, a szabályozások harmonizációja hiányzik és a magánszektor aktivitása alacsony. Egy másik, Egyiptommal kapcsolatban végzett kutatás (Said-Shelaby, 2014) kizárólag az arab országokkal szembeni kereskedelmet vizsgálta, amelynek oka, hogy az arab országok az 1950-es évektől kezdve több egyezményt is aláírtak, ennek ellenére a teljes kereskedelem mindössze 11 százaléka zajlott közöttük, míg ugyanez az arány EUországok esetében 60 százalék. A modell föbb eredménye a közös határ jelenlétének negatív előjele, amely arra utal, hogy a közös határ nem javítja az exportot, amit a szerzők arra vezettek vissza, hogy nagyon gyenge a határokon az infrastruktúra, ami nem teszi lehetővé nagy hajórakományok szállítását, ezért az exportőrök és importőrök előnyben részesítik a levegőben történő szállítást. A gravitációs modellek által kimutatható irányvonal Egyiptom számára az infrastruktúra javításának szükségessége.

Egy az EU és az USA között létrejövő kereskedelmi egyezmény jövőbeli hatásait vizsgáló elemzés gravitációs modell segítségével elemezte, hogy milyen hatással vannak a mezőgazdasági termékek forgalmára a vámok és nem vámjellegủ akadályok. Az eredményeik alapján a termékforgalom létrejöttét negatívan befolyásolták a vámok és nem vámjellegü akadályok, ugyanakkor utóbbi kereskedelemcsökkentő hatása nagyobbnak bizonyult. Ugyanezt vizsgálták az EU és az USA vonatkozásában is. Ha az EU USA-ba irányuló exportját tekintjük, akkor az USA által kivetett vámok nem befolyásolták szignifikánsan az EU exportját az országba. Fordított esetben viszont az EU által az USA termékeire kivetett vámok szignifikánsan csökkentették az USA EU-ba irányuló mezőgazdaságitermék-exportját. A többi OECDország közötti termékforgalmat is visszavetették a vámok, de lényegesen kisebb mértékben, mint az EU és az USA között (European Parliament, 2014).

A felvázolt modellek a jövedelmet és a távolságot mind tartalmazták, a népesség szerepeltetésével kapcsolatban már nem ilyen egyértelmủek a felvázolt modellek. A többi magyarázóváltozó nagymértékben függ a vizsgálat céljától és a vizsgált országtól, integrációtól. Ennek oka az, hogy számos tényező befolyásolja egy-egy ország vagy országcsoport kereskedelmét, például a közös nyelv, a közös határok, 


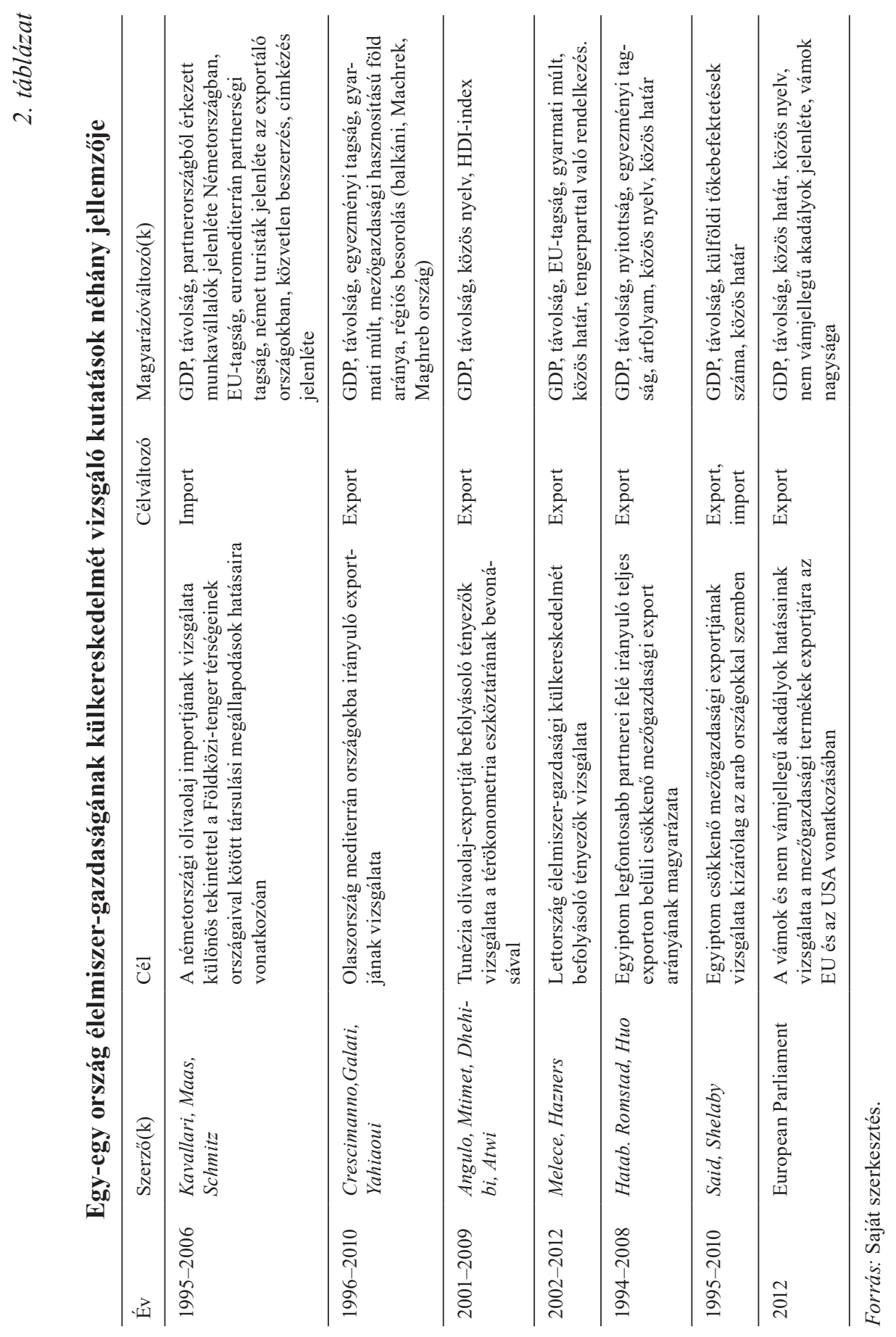


A külkereskedelem akadályainak számszerüsítése egy magyarországi...

történelmi múlt vagy például az integrációs tagság. A Magyarország exportját leíró modellben a szakirodalom alapján a jövedelem, távolság, népesség, a közös határ, integrációs tagság változókat építem be a modellbe, ezeket a legtöbb leírt modell tartalmazza. Fontosnak tartom továbbá a vámok és nem vámjellegủ akadályok hatásainak számszerüsítését is, hiszen az integrációelméleteknek központi elemét képezik. Ugyanakkor a vámok és nem vámjellegủ akadályokat beépítő modellek módszertana rendkívül bonyolult, ennek kiküszöbölésére kísérletet tettem egy olyan index beépítésére, amely egy-egy ország kereskedelmének liberalizáltságát egyetlen indexben ragadja meg.

\section{A magyar élelmiszer-gazdaság gravitációs modellje}

Adatok

A magyar élelmiszer-gazdaság külkereskedelmének vizsgálatára alkalmazott gravitációs modellt keresztmetszeti elemzésként hajtottam végre a 2015-ös évre. A célom az volt, hogy feltárjam a magyarországi élelmiszer-gazdaság exportját befolyásoló tényezőket, valamint mérjem azok hatását. Továbbá, hogy megvizsgáljam a gravitációs modellekben korábban még nem alkalmazott mutatónak, a külkereskedelmi lehetőségek fokának, alkalmazhatóságát.

A modellben használt eredményváltozó a magyarországi mezőgazdasági és élelmiszerexport (két számjegyủ HS 01-24 kódok) nagysága dollárban kifejezve a KSH adatai alapján. A magyarázóváltozók között szerepeltek a gravitációs modellben már megszokott változók, úgymint az importáló ország GDP-je, a népesség és az országpárok közötti távolság. Előbbi kettő a Világbank, a távolság pedig a CEPII adatbázisából származik, amelyet egy az Agrárgazdasági Kutatási Intézetben folyó külkereskedelmi kapcsolatokat vizsgáló kutatás részeként gyűjtöttünk össze. Az alapvető magyarázóváltozók mellett az adatbázis tartalmazta a mezőgazdaság részesdését a GDP-ből, melyet szintén a Világbank adatbázisa szolgáltatott. A modellben alkalmaztam olyan mutatót, amelyeket eddig a szakirodalomban nem alkalmaztak. Ez a változó a külkereskedelmi lehetőség foka, amely a Heritage Foundation kimutatásaiból származik. A 0 és 100 közötti értéket felvevő mutató a külkereskedelem vám- és nem vámjellegü akadályoktól való mentességét jelzi. Minél magasabb érték tartozik egy adott országhoz, annál inkább tekinthető liberalizáltnak a kereskedelme. A mutató használata azért fontos, mert a nemzetközi kereskedelem és az integrációelméletek egyik központi eleme a vámok és nem vámjellegü aka- 
dályok, ugyanakkor a korábbi kutatásokban alkalmazott számítások a vámokra és különösen a nem vámjellegủ akadályokra vonatkozóan rendkívül bonyolultak, ezért e változó használatával egyszerủbbé válhat a kereskedelmi korlátozó hatások megragadása. A szakirodalomban a mutató használata eddig nem terjedt el, mert ugyan az index elérhető 1995-re visszamenőleg, de akkor még csak mindössze 101 országra vonatkozóan tartalmazott adatot. A mintaelemszám 140-160 országra növekedett az elkövetkező években, majd 2009-töl már folyamatosan 180 országra volt elérhető adat. A szakirodalmakat tekintve jellemzően legfeljebb 2012-ig, de általában korábbi adatokra illesztettek gravitációs modellt, amely időszakra még nem állt rendelkezésre az index tartósan, sok országra. Az elkövetkező években ugyanakkor már hoszszabb idősoron is alkalmazhatóvá válhat.

Az adatbázis tartalmazott dummy változókat is arra vonatkozóan, hogy EU-tage az országpár másik tagja és Magyarországnak van-e közös határa az importáló országgal.

Az adatbázis összeállítása után a dummy változók kivételével kiszámítottam az összes változó természetes logaritmusát, hiszen a gravitációs modell alapvetően multiplikatív formában írható fel, mely átalakítható lineáris modellé a logaritmus segítségével. Az adatokkal kapcsolatban fontos megjegyezni, hogy Magyarország 158 országba exportálta az élelmiszer-gazdaság termékeit 2015-ben. Az adatbázis megalkotása során voltak olyan országok, amelyekre nem volt elérhető adat a GDP tekintetében, így az adatbázis tisztítása során első körben kiesett 4 ország, melyek a magyar élelmiszerexport teljes értékének mindössze 0,03 százalékát teszi ki. Az alap adatbázis így 154 megfigyelésből állt. A modellt az SPSS programcsomag segítségével készítettem el.

A magyar élelmiszer-gazdaság exportjának befolyásoló tényezői

Első lépésben korrelációs mátrixot írtam fel a logaritmizált változók közötti lineáris kapcsolat meglétének feltérképezésére, ennek segítségével megállapítható egyrészt, hogy mely változók állnak szignifikáns kapcsolatban az eredményváltozóval és milyen mértékben. Másrészt, ha a regressziós modell esetében fennáll a multikollinearitás veszélye, akkor a becslések standard hibái olyan nagyok, hogy már nem megbízhatóak a becslések. A multikollinearitás kiszürésére egyrészt a változók korrelációs mátrixot vizsgáltam a változók közötti páronként kapcsolat tisztázására, másrészt a VIF-mutatót, más néven varianciainflációs tényezőt, amellyel a változócsoportok között fennálló korreláció által okozott multikollinearitás nagyságát mé- 
rem. A VIF mutató küszöbértékére vonatkozóan a mutató 5 feletti értéke esetén erős, zavaró multikollinearitásról beszélünk, ekkor káros mértékủ a magyarázóváltozók összefüggése (Kovács, 2008).

A létrehozott korrelációs mátrix segítségével az eredeti változók logaritmusa közötti kapcsolatot vizsgáljuk. A korrelációk alapján elsőként megállapítható, hogy az export minden változóval szignifikáns kapcsolatban áll, amik közül a leggyengébb a népességgel $(r=0,229)$ és a közös határral $(r=0,327)$ való együttmozgás. Közepes erősségü kapcsolatban áll az export a mezőgazdaság GDP-hez viszonyított arányával $(r=-0,532)$, az EU-tagsággal $(r=0,573)$, a távolsággal $(r=-0,585)$ és a GDP-vel $(r=0,605)$. Az export nagysága leginkább a külkereskedelmi lehetőségekkel $(r=$ 0,636), azaz a vámokkal és a nem vámjellegủ akadályokkal függ össze (lásd a 3 . táblázatot). A negatív irányú kapcsolat a két változó ellentétes mozgását fejezi ki, azaz például minél nagyobb a két ország közötti távolság, annál kisebb lesz közöttük a termékforgalom. Ugyanez elmondható a mezőgazdasági termelés GDP-hez viszonyított arányának növekedése esetében is. Ha egy országban magas a mezögazdasági termelés aránya a GDP-n belül, akkor kevesebb importra szorul. Ehhez hozzá kell tenni, hogy ez utóbbi mutató nem tájékoztat arról, hogy milyen színvonalú és szerkezetủ a mezőgazdasági termelés az adott országban, pusztán azt mutatja, hogy mekkora részt képvisel a GDP-ből a mezőgazdaság termelési értéke. A külkereskedelem lehetőségének foka pozitív előjelü korrelációt mutat, ennek oka, hogy a mutató magasabb értéke jelenti a kereskedelem magasabb szintü liberalizáltságát, amely nagyobb exportot tesz lehetővé. Ezzel szemben, ha növekednek az exportáló országgal (Magyarországgal) szemben alkalmazott korlátok (kisebb lesz a mutatók értéke), akkor kevesebb terméket fog kivinni az exportáló ország.

A változók közötti korreláció lehetőségét vizsgálva néhány független változó között is felfedezhető erőteljes kapcsolat. Ahogyan feltételezhető volt a korábbi kutatások alapján, a GDP és a népesség nagysága szoros kapcsolatban állnak egymással $(r=0,712)$, továbbá kimutatható kapcsolat a távolság és az EU-tagság $(r=-0,552)$, illetve a külkereskedelem liberalizáltsága és a mezőgazdaság GDP-ből való részesedése $(r=-0,595)$ között is. A változók közötti kapcsolat torzíthatja a regressziós modellt, amelyet a modell felírásakor a VIF-mutató kiszámításával is tesztelünk.

A megfelelően illeszkedő regressziós modell megtalálásához első körben egy a legtöbb változót tartalmazó modellt futtatunk, hogy megvizsgáljuk a multikollinearitás jelenlétét, hiszen a korrelációs mátrix alapján látható volt, hogy néhány változó megsértheti a változók korrelálatlanságára vonatkozó előfeltételt. Ez a modellben is megmutatkozott, legerősebben az EU-tagság és a távolság, a partner ország GDP-je 


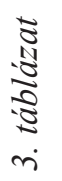

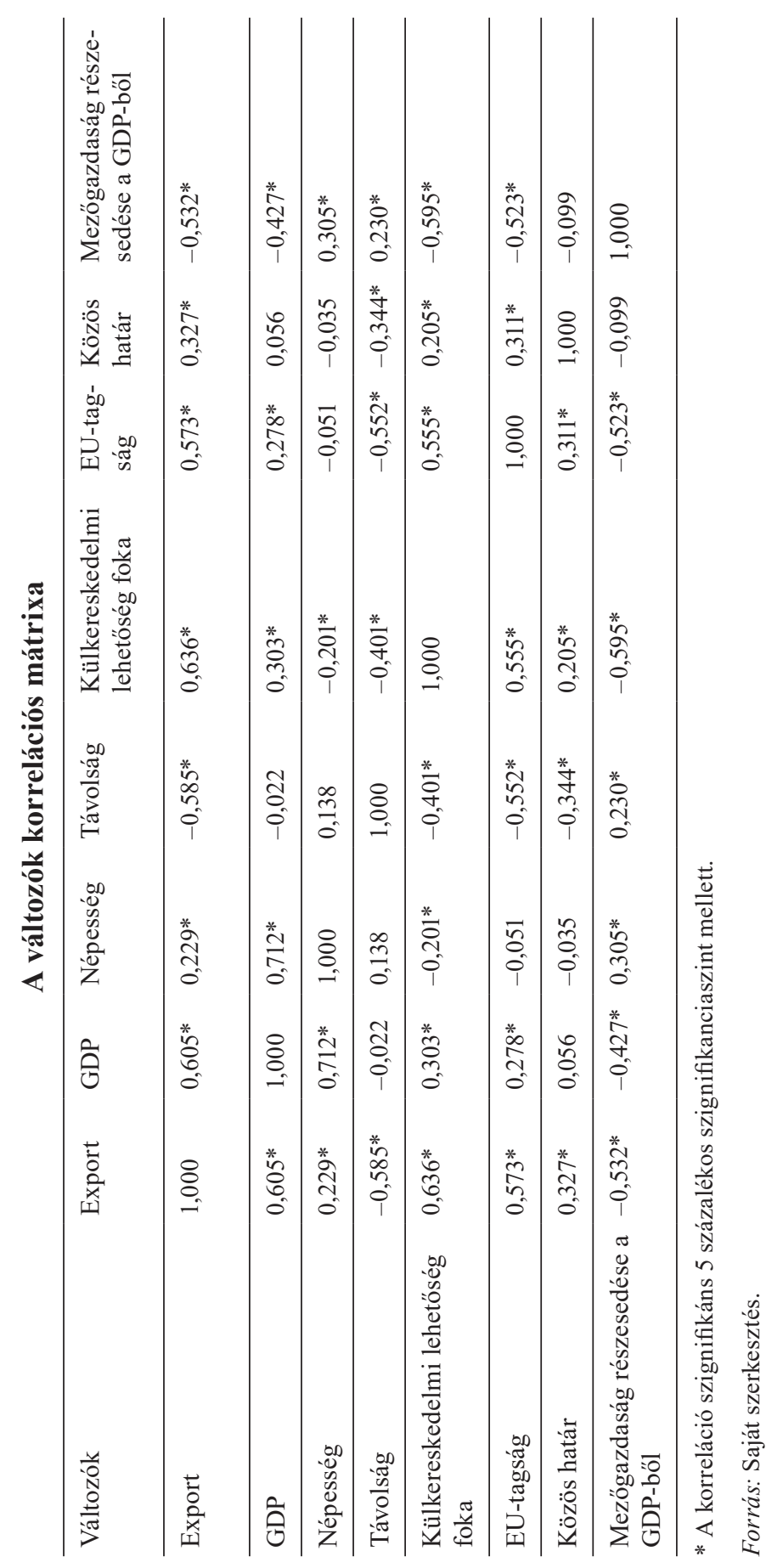


és a népesség esetén. A népesség nagymértékủ multikollinearitást okozott a modellben, hiszen már a korrelációk vizsgálata esetén megmutatkozott, hogy kismértékben korrelál az exporttal, viszont erősen összefügg a GDP-vel.

A magyar élelmiszer-gazdaság exportját leíró modellben a kivitelt a partnerország jövedelme, a két ország közötti távolság és a külkereskedelem akadályozottságának mértéke befolyásolja. Az így létrehozott modell 139 országot tartalmaz, amelynek oka, hogy további néhány ország esetében nem volt elérhető adat a külkereskedelmi lehetőség fokát tekintve. A kezdeti 158 megfigyeléshez képest összességében 19 ország adata esett ki, de ezek a teljes magyar exportot tekintve annak mindössze 0,27 százalékát érték el a vizsgált évben. A kialakult modell 83,3 százalékban magyarázza az export különböző értékeit, illetve a kivitel és a magyarázóváltozók összessége között erös kapcsolat van $(R=0,7)$. A szignifikanciaszint alapján a modell alkalmazható Magyarország élelmiszer-gazdasági exportjának vizsgálatára.

4. táblázat

\section{A magyarországi élelmiszer-gazdaság gravitációs modelljének eredményei,} 2015

\begin{tabular}{llll}
\hline Paraméterek & $\begin{array}{l}\text { Paraméterek együtthatója } \\
(\beta)\end{array}$ & $\begin{array}{l}\text { Szignifikancia } \\
\text { értéke }\end{array}$ & VIF-mutató \\
\hline Konstans & $-10,698$ & 0,090 & \\
Importáló ország GDP-je & 0,896 & 0,000 & 1,111 \\
Távolság & $-1,997$ & 0,000 & 1,201 \\
Külkereskedelmi lehetőség foka & 4,306 & 0,002 & 1,320 \\
\hline
\end{tabular}

Forrás: Saját szerkesztés.

A multikollinearitás VIF-mutatója alapján gyenge mértékủ a korreláció a változók között, így a magyarázóváltozók korrelálatlanságára vonatkozó feltétel teljesül. A paraméterek értelmezése során figyelembe kell venni, hogy az adatok logaritmusát vettem, a változók logaritmusa között van a lineáris összefüggés, így az regressziós együtthatókat az eredeti változók között rugalmasságként kell értelmezni. Ennek megfelelően a modell szerint az importáló ország GDP-jének bármilyen szintről történő 1 százalékos növekedésének hatására a Magyarországról származó behozataluk átlagosan 0,9 százalékkal növekszik. A távolsággal negatív irányú kapcsolatról be- 
szélhetünk. Abban az esetben, ha Magyarország egy 1 százalékkal távolabb eső országba exportál, akkor az export mértéke átlagosan 2 százalékkal fog csökkenni. A legnagyobb hatást a külkereskedelmet akadályozó tényezőket számszerűsítő változó mutatja, ez alapján a vámok és nem vámjellegű akadályok bármilyen szintről történő 1 százalékos csökkenésének hatására (nagyobb lesz a külkereskedelmi lehetöség foka mutató értéke a partnerországban) a magyar export átlagosan 4,3 százalékkal növekszik a partnerország irányába (lásd a 4. táblázatot).

A modell eredményei alapján az országok közötti távolság és különösen a vámok és nem vámjellegủ akadályok számottevően korlátozzák a külkereskedelmi termékforgalom zavartalan áramlását. Mindez alátámasztja a napjainkban zajló integrációs folyamatokat, amely szerint az egymáshoz közel elhelyezkedő országok egyre mélyebb és a vámokon túlmutató gazdasági integrációkat hoznak létre, nem csak a vámok leépítése miatt, hanem a sok esetben a vámok eltörlése után is korlátot jelentő szabályozási, egészségügyi elöírások különbségeinek és egyéb nem vámjellegü akadályok megszüntetése érdekében. Ennek vizsgálatára egy olyan mutatót alkalmaztam, amelyet korábban még nem használtak a gravitációs modellekben. Ez a változó a külkereskedelmi lehetőségek foka, amely alkalmazhatónak bizonyult az külkereskedelmi termékforgalom magyarázatában. Az indikátor beépítésével lehetőség nyílik a vámok és nem vámjellegủ akadályok egyszerübb számszerüsítésére az eddigi kutatásokban alkalmazott számításokhoz képest.

\section{Összegzés}

A magyarországi élelmiszer-gazdaság külkereskedelmi tevékenységének modellezésére használt gravitációs modell kimutatta a szakirodalom alapján is sejtett összefüggést, mely szerint a távolság ellentétes irányú, míg az importőr ország GDPje pozitív irányú, szignifikáns hatást gyakorol az export mértékére. A modell újitása, hogy olyan változót is számításba vett, amelyek az eddigi kutatásokban nem szerepelt. Ez a mutató a vámok és nem vámjellegü akadályok mértékét számszerüsítő külkereskedelmi lehetőségek foka, amely a modellben alkalmazhatónak bizonyult az export magyarázatában. Ennek fontosságát az indokolja, hogy a vámok és különösen a nem vámjellegü akadályok beépítése a gravitációs modellekbe rendkívül nehézkes, a legtöbb élelmiszer-gazdaság területén alkalmazott modell nem alkalmaz erre vonatkozóan számításokat, ugyanakkor ezek a nemzetközi kereskedelem legfőbb akadályai. Az indikátor a jövőben alkalmazhatóvá válhat gravitációs modellekben paneladatok esetében is, hiszen mára már rendelkezésre áll hosszabb idősoron is több 
mint 150 országra vonatkozóan. A tanulmányban bemutatott modell ennek megfelelően tovább fejleszthető több év adatának vizsgálatával, amellyel az országpárok közötti egyedi kapcsolat jellege jobban megragadható és a becslés is pontosítható.

\section{Irodalomjegyzék}

Angulo, A. M. - Mtimet, N. - Dhehibi, B. - Atwi, M. - Youssef, O. B. - Gil, J. M. - Sai, M. B. [2011]: A revisited gravity equation in trade flow analysis: an application to the case of Tunisian olive oil exports. Investigaciones Regionales, No. 21., 225-239. o.

Burfisher, M. E. - Robinson, S. - Thierfelder, K. [2004]: Regionalism: Old and New, Theory and Practice. Agricultural policy reform and the WTO: where are we heading? International Conference, June 23-25, Capri, Italy.

Bojnec, S. - Fertö, I. [2015]: Institutional Determinants of Agro-Food Trade. Transformations Business \& Economics, Vol. 14., No. 2., 35-52. o.

Cheng, I. H. - Wall, H. J. [2005]: Controlling for Heterogeneity in Gravity Models of Trade and Integration. Federal Reserve Bank of St. Louis Review, 1-2., 49-64. o.

Clark, X. - Dollar, D. - Micco, A. [2004]: Port efficiency, maritime transport costs, and bilateral trade. Journal of Development Economics, Vol. 75., No. 2., 417-450. o.

Clausing, K. A. [2001]: Trade creation and trade diversion in the Canada - United States Free Trade Agreement. Canadian Journal of Economics, Vol. 34., No. 3., 677-696. o.

Crescimanno, M. - Galati, A. - Yahiaoui, D. [2013]: Determinants of Italian agri-food export in non-EU Mediterranean Partner Countries: an empirical investigation through a gravity model approach. $A$ Mediterranean Journal of Economics, Vol. 12., No. 4., 46-54. o.

Ethier, W. J. [1998]: The New Regionalism. The Economic Journal, Vol. 108., No. 449., 1149-1161. o.

European Parliament [2014]: Risks and Opportunities for the EU Agri-food Sector in a Possible EU-US Trade Agreement. Letölthető: http:/www.europarl.europa.eu/RegData/etudes/ STUD/2014/514007/AGRI_IPOL_STU(2014)514007_EN.pdf Letöltve: 2016. október 14.

García, E. C. - Pabsdorf, N. M. - Herrera, E. G. [2013]: The gravity model analysis: an application on MERCOSUR trade flows. Journal of Economic Policy Reform, Vol. 16., No. 4., 336-348. o.

Hatab, A. A. - Romstad, E. - Huo, X. [2010]: Determinants of Egyptian Agricultural Exports: A Gravity Model Approach. Modern Economy, Vol. 1., No. 3., 134-143. o.

Hettne, B. [2005]: Beyond the 'New' Regionalism. New Political Economy, Vol. 10., No. 4., 543-570. o.

Hummels, D. [2007]: Transportation Costs and International Trade in the Second Era of Globalization. Journal of Economic Perspectives, Vol. 21., No. 3., 131-154. o.

Jámbor Attila [2014]: A horizontális és vertikális ágazaton belüli agrárkereskedelem meghatározó tényezői az EU új tagországaiban. Közgazdasági Szemle, Vol. 61., No. 5., 544-565. o.

Jayasinghe, S. - Sarker, R. [2007]: Effects of Regional Trade Agreements on Trade in Agrifood Products: Evidence from Gravity Modeling Using Disaggregated Data. Review of Agricultural Economics, Vol. 30., No. 1., 61-81. o.

Kavallari, A. - Maas, S. - Schmitz, P. M. [2008): Explaining German imports of Olive oil: evidence from a gravity model. Paper prepared for presentation at the 12th EAAE Congress 'People, Food and Environments: Global Trends and European Strategies', Belgium, Gent.

Kovács Péter [2008]: A multikollinearitás vizsgálata lineáris regressziós modellekben. Statisztikai Szemle, Vol. 86., No. 1., 38-67. o.

Kürti A. - Stauder M. - Wagner H. - Kürthy Gy. [2007]: A magyar élelmiszer-gazdasági import dinamikus növekedésének okai. Agrárgazdasági Kutató Intézet, Budapest. 126 o. 
Limao, N. - Venables, A. J. [2001]: Infrastructure, Geographical Disadvantage, Transport Costs, and Trade. The World Bank Economic Review, Vol. 15., No. 3., 451-479. o.

Lipsey, R. G. [1957]: The Theory of Customs Unions: Trade Diversion and Welfare. Economica, Vol. 24., No. 93., 40-46. o.

Martinez-Zarzoso, I. - Nowak-Lehman, F. [2003]: Augmented Gravity Model: An Empirical Application to MERCOSUR-European Union Trade Flows. Journal of Applied Economics, Vol. 6., No. 2., 291-316. o.

Melece, L. - Hazners, J. [2014]: Evaluation of Latvia's agri-food trade using the gravity model. Actual Problems of Economics, Vol. 159., No. 9., 518-526. o.

Michalopoulos, C. - Tarr, D. (2004): Are customs unions economically sensible in the commonwealth of independent states. World Bank, Washington, 34. o.

Paiva, C. [2008]: Assessing Protectionism and Subsidies in Agriculture - A Gravity Approach. Journal of International Development, Vol. 20., No. 5., 628-640. o.

Palánkai Tibor [2004]: Az Európai Integráció Gazdaságtana. Aula Kiadó, Budapest, 502 o.

Robson, P. [2002]: The Economics of International Integration. Routledge, New York, 339 o.

Said, M. A. - Shelaby, A. A. [2014]: Potentials of Egypt Agricultural Bilateral Trade with the Arab Countries: Gravity Model Evidence. International Journal of Food and Agricultural Economics, Vol. 2., No. 1., 133-144. o.

Salvatore, D. [2004]: International Economics. John Wiley \& Sons, New York, 836 o.

Scitovsky, T. [1958]: Economic Theory and Western European Integration. Routledge, New York, 153 o.

Serrano, $R$. - Pinilla, $V$. [2012]: The long-run decline in the share of agricultural and food products in international trade: a gravity equation approach to its causes. Applied Economics, Vol. 44., No. 32., 4199-4210. o.

Söderbaum, F. [2003]: Theories of New Regionalism. In: Söderbaum, F. - Shaw, T. M. (eds): Theories of New Regionalism. Palgrave Reader, Basingstoke, 1-21. o.

Zahniser, S. S. - Pick, D. - Pompelli, G. - Gehlhar, M. J. [2002]: Regionalism in the Western Hemisphere and its Impact on U.S. Agricultural Exports: A Gravity-Model Analysis. American Journal of Agricultural Economics, Vol. 84., No. 3., 791-979. o. 